\title{
The Determinants of Academic Dishonesty in College Student
}

\author{
Wahyu Maulana Firdaus ${ }^{1}$ and Solicha ${ }^{2}$ \\ ${ }^{1,2}$ Faculty of Psychology, State Islamic University Syarif Hidayatullah, Jakarta, Indonesia \\ *E-mail: maufirda@gmail.com
}

\begin{abstract}
This study aimed to investigate the effect of moral disengagement (professor and student), perceived opportunity, culture (collectivism-individualism), and religiosity (organizational religiosity, non-organizational religiosity, and intrinsic religiosity) on academic dishonesty in college student. The data was collected from 515 undergraduate students of the state college in Java, by nonprobability sampling technique. The data analysis used multivariate regression analysis. The result indicated that the model was saturated. Moral disengagement student predicted all of the dependent variables. Further, moral disengagement professor only significantly predicted cheating and facilitating academic dishonesty. Meanwhile perceived opportunity and collectivism predicted cheating, and non-organizational religiosity predicted fabrication. Future research is needed to determine the other factors which influence academic dishonesty and use other a regression model.
\end{abstract}

Keyword: academic dishonesty, multivariate regression analysis, unethical behavior

\section{Introduction}

The goal of education is to actualize the potential of individuals to become more knowledgeable and refined. According to the Republic of Indonesia Law No. 20 of 2003 on National Education System, article 1 paragraph 1 , one of the goals of education is to develop moral virtues. However, unfortunately, unethical behaviors the academy, such as cheating, plagiarism, and data fabrication are still common. In Indonesia, in the last two years, with varying degrees and forms of behavior, the rate of academic dishonesty is approximated at over 50\% (Dewi, 2016; Little Circle Foundation, 2015; Paramitha, 2016, Syahrina \& Andini, 2017). This problem of academic dishonesty is not unique to Indonesian education, as it is also found abroad. Some studies conducted in the United States, for example, shows that from 2011 to 2016 more than $50 \%$ of students committed some form of academic dishonesty, including fraudulence or plagiarism, (George, 2016; Josephson Institute, 2012; Ledesma, 2011; Stanescu \& Iorga, 2013). Academic dishonesty has also been found to predict unprofessional behavior in the workplace. Harding, Carpenter, Finelli, and Passow (2004) reported that students who engaged in academic dishonesty were more likely to commit unethical behavior at workplace, such as falsifying records and data, corruption, and neglecting job quality.
Academic dishonesty is a multidimensional construct. Academic dishonesty can be defined as is deliberate deception, where individuals gain recognition of their work without authority (plagiarism), using unauthorized materials (cheating), falsifying data (fabrication), harming others and facilitating in academic dishonesty (facilitating), such as giving or receiving unauthorized help and receiving benefits over the work of others (Gehring \& Pavela, 1994; Meng, Othman, D'Silva, \& Omar, 2014). Several factors influence academic dishonesty. In general, academic dishonesty is influenced by factors individual, situational, and attitudinal (Jurdi, Hage, \& Chow, 2011). Individual factors include: personality (Brunnell, Staats, Hupp, \& Barden, 2010; Etter, Cramer, \& Finn, 2007; Williams, Nathanson, \& Paulhu, 2010), cognitive abilities (Geddes, 2011; Gino \& Ariely, 2011; Williams, Nathanson, \& Paulhu, 2010), moral disengagement (Dettert, Trevino, Sweitzer, 2008, Farnesse, Tramontano, Fida \& Paciello, 2011), moral identity (Hardy, Walker, Laman, \& Olsen, 2011; Reynold \& Ceranic, 2007, Wowra, 2007), and self-control (Aaron, 2004). The situational factors that affect academic dishonesty include: cheating friends (Farnesse, Tramontano, Fida \& Paciello, 2011), lack of strong rules and penalties for perpetrators of fraud (Macdonald \& Carroll, 2006; Martin, 2005), perceived opprtunity (Bolin, 2004), culture (Martin, 
2011), the desire to get high scores (Underwood \& Szaboo, 2003), religiosity (Bloodgood, Turnley, \& Mudrack, 2007), religious priming (Randolph-Seng \& Nielsen, 2007), class structure, ethical instruction (Bloodgood, et al., 2007), as well as opportunities (Aaron, 2004), and role models (Sonnentag \& Mc Daniel, 2012). Lastly, the attitudinal factors include neutralization and moral disengagement (Farnese et al., 2011). In this study, the researchers focused on moral disengagement, perceived opportunity, and culture as predictors of academic dishonesty.

Moral disengagement is the thought that ignores the one's moral compass and justifies unethical behavior (Bandura, 2002). Moral disengagement has been found to be significantly associated with unethical behavior. Drawing from Bandura's social cognitive theory, Farnese et al. (2011) proposed teachers' (e.g., dehumanization, attribution of blame, and distortion of consequences) and friends' behavior (including diffusion of responsibility, displacement of responsibility, and advantageous comparison) that predict students' moral disengagement. Therefore, it can be interpreted that the more one does the mechanism of moral disengagement, then the more the person is likely to do academic dishonesty (Farnese et al., 2011). Based on the literature on moral disengagement in academic context, we hypothesized that:.

Hypothesis 1a: Moral disengagement professor positively predicted on cheating, fabrication, facilitating, and plagiarism.

Hypothesis 1b: Moral disengagement student positively predicted by cheating, fabrication, facilitating, and plagiarism.

Another study claimed that academic dishonesty was influenced by perceived opportunity (Bolin, 2004). Perceived opportunity is the individual's perception of frequency and acceptance of unethical behaviors in the academic environment, and its probability of being detected (Bolin, 2004). In practice, perceived opportunity is related to the environmental situations that provide an individual opportunity to engage in academic dishonesty. Perceived opportunities can be reduced when fraudulent behavior can be detected and results in severe punishment (Dellaportas, 2013). We assumed that perceived opportunity also positively predicted by each dimension of academic dishonesty. Students who perceived the opportunity to conduct unethical behavior more strongly would be more likely to do cheating, fabrication, facilitating, and plagiarism.
Hypothesis 2: perceived opportunity is positively associated with cheating, fabrication, facilitating, and plagiarism.

According to Martin (2011), cultural orientation (i.e., collectivism vs. individualism) is a factor that also predicts academic dishonesty among students. Triandis et al. (1988) argued that collectivistic-oriented culture prioritizes the goal and existence of groups over it is of individual. In contrast, in individualistic culture, individual needs take precedence over the goals and needs of the group. We assumed that collectivistic culture orientation negatively predicts each dimension of academic dishonesty. In other words, students with individualistic cultural orientation would be more likely to do cheating, fabrication, facilitating, and plagiarism rather than collectivistic students.

Hypothesis 3a: Collectivism negatively predicts cheating, fabrication, facilitating, and plagiarism.

Hypothesis 3b: Individualism positively predicts cheating, fabrication, facilitating, and plagiarism.

Other studies result that academic dishonesty is influenced by religiosity (Huelsman et al., 2006; Storch \& Storch, 2001). Fridayanti (2015) cites Koenig's definition that religiosity is a system that religion is also related to individual intrinsic, also its interactions with society and its operations through an organization. From this definition, Koenig divides religiosity into three dimensions, i.e., organizational religiosity, non-organizational religiosity, and intrinsic religiosity (Koenig, Parkerson, \& Meador, 1997). We assumed that all of the dimensions of religiosity would negatively predict each dimension of academic dishonesty.

Hypothesis 4a: Organizational religiosity negatively predicts cheating, fabrication, facilitating, and plagiarism.

Hypothesis 4b: Non-organizational religiosity negatively predicts cheating, fabrication, facilitating, and plagiarism.

Hypothesis 4c: Intrinsic religiosity negatively predicts cheating, fabrication, facilitating, and plagiarism. 


\section{Method}

Sample. Participants of this study were the students of state universities in Java. According to data from Statistics Supervisory Agency of the Republic of Indonesia (2017) that population of students of state universities in Java is more one million. According to Yamane's table of sample size, for a population of more than one hundred thousand, a sample size of 400 is required, with confidence level is $95 \%$. The sample criterion in this study is active student per 2017. The sampling technique that used in this study is non-probability sampling by the accidental method. In this study, 515 individuals were recruited, consisting of $374(72,7 \%)$ females, 299 $(58,1 \%)$ Javanese, $92(17,8 \%)$ Sundanese, and 124 $(24,1 \%)$ other ethnic. Respondents were 206 $(39,9 \%)$ eighth semester, $131 \quad(25,4 \%)$ sixth semester, and $97(18,8 \%)$ fourth semester.

Research Design. This study used non-experimental design, aimed to examine the association among several independent variables (moral disengagement, perceived opportunity, religiosity and collectivism with academic dishonesty.

Instrument and Measurement. This study used several instruments for measure the constructs. Academic dishonesty was measured by using a 20 -item scale (5 items for each dimension) from Dewi's Academic Dishonesty Scale that was constructed based on Pavela's Theory (Dewi, 2016). The items on this scale measured the frequency of cheating, fabrication, facilitating, and plagiarism using 5 Likert scale ranging from 0 (never) to 4 (always). In this study, the scale was retested by confirmatory factor analysis (CFA) for each dimension (Firdaus, 2017). The result is all of item was unidimensional for each dimension, i.e. cheating (chi-square $=4,420, \mathrm{df}=3, \mathrm{p}$-value $=$ 0,2195, RMSEA $=0,030$ ), fabrication (chi-square $=$ 10,971 , df $=5$, p-value $=0,0520$, and RMSEA $=$ 0,048), facilitating (chi-square $=3,240, \mathrm{df}=4$, p-value $=0,5185$, and RMSEA $=0,000)$, and plagiarism (chi-square $=7,542, \mathrm{df}=4, \mathrm{p}$-value $=$ 0,1099, and RMSEA $=0,041$ ).

Moral disengagement was measured using a 12-item scale (6 items for each dimension) from Farnese's Academic Moral Disengagement Scale (Farnese et al., 2011). The items on this scale aim to measure attitude toward academic dishonesty behavior, and measure level of academic morality. Participants responded to 4-point Likert scales ranging from 1 (very disagree) to 4 (very agree). In this study, the scale was retested by CFA for each dimension (Firdaus, 2017). The result is all of item was unidimensional for each dimension, i.e. moral disengagement professor $($ chi-square $=11,809, \mathrm{df}=$ 6 , $\mathrm{p}$-value $=0,0664$, and RMSEA $=0,043$ ) and moral disengagement student (chi-square $=7,166$, $\mathrm{df}=6$, p-value $=0,3058$, and RMSEA $=0,019$ )

The perceived opportunity was measured using an 8-item scale from Bolin's Perceived Opportunity Scale (Bolin, 2004). The items on this scale measured individuals' perceived frequency and acceptance of unethical behaviors in the academic environment. Response categories were 4-point Likert scales ranging from 1 (very disagree) to 4 (very agree). In this study, the scale was retested by CFA (Firdaus, 2017). The result is all of item was unidimensional (chi-square $=19,824$, $\mathrm{df}=14$, p-value $=0,1358$, and RMSEA $=0,028$ ).

Collectivism was measured using a 9-item scale adapted from the Oyserman's Collectivism and Individualism Scale (Oyserman, 1993). The items on this scale measured one's leaning towards himself or the group, with 4-item Likert scales ranging from 1 (very disagree) to 4 (very agree) as the response categories. In this study, the scale was retested using CFA for each dimension (Firdaus, 2017). The result is all of item was unidimensional (chi-square $=6,227, \mathrm{df}=6, \mathrm{p}$-value $=0,3982$, and RMSEA $=0,009$ ), but three items of collectivism must be dropped out.

Religiosity was measured using the 15-item Firdaus's Religiosity Scale (Firdaus, 2017). The items on this scale aim to measure individual level of religiosity (organizational, non-organizational, intrinsic). Response categories were 4-item Likert scale ranging from 1 (very disagree) to 4 (very agree). In this study, the scale was tested using CFA for each dimension (Firdaus, 2017). The CFA suggested that all items were unidimensional for each dimension, i.e. organizational religiosity (chi-square $=3,946$, df $=3$, p-value $=0,2673$, and RMSEA $=0,025)$, non-organizational religiosity (chi-square $=2,958, \mathrm{df}=3, \mathrm{p}$-value $=0,3981$, and RMSEA $=0,000)$, and intrinsic religiosity (chi-square $=6,085, \mathrm{df}=4, \mathrm{p}$-value $=0,1929$, and RMSEA $=0,032$ ).

Procedure. Data was collected in several state universities in Java in April and May 2017. Participants were asked to answer several items through online questionnaire made in Google Form. 
To investigate data authenticity, the researcher asked some students that personally trusted for each province about subjects, data filling, etc.

\section{Results}

The researchers categorized each dimension by factor score after we had a set of valid scales (see Table 1). Then, the hypotheses with multivariate regression analysis by Mplus7 were examined. The result was that the model was saturated $(\mathrm{df}=0$, CFI=1). The model was significant on cheating, fabrication, facilitating, and plagiarism (see Table 2). Then, the regression coefficient for each dimension was analyzed (see Table 3).

Table 1

Score Category

\begin{tabular}{lccc}
\hline \multicolumn{1}{c}{ Variable } & \multicolumn{3}{c}{ Category } \\
Cheating & 93 & 310 & 112 \\
Fabrication & 11 & 504 & 0 \\
Facilitating & 108 & 283 & 124 \\
Plagiarism & 1 & 514 & 0 \\
MDP & 157 & 224 & 134 \\
MDS & 137 & 272 & 106 \\
Perceived opportunity & 6 & 503 & 6 \\
Collectivism & 26 & 472 & 17 \\
Organizational & 0 & 503 & 12 \\
Non-organizational & 13 & 487 & 15 \\
Intrinsic & 139 & 228 & 148 \\
\hline
\end{tabular}

$\mathrm{N}=515$

Table 2

Result of Multivariate Regression Analysis

\begin{tabular}{lccc}
\hline \multicolumn{1}{c}{ Variable } & $\mathrm{R}^{2}$ & $\mathrm{t}$ & $\mathrm{p}$ \\
\hline Cheating & 0.403 & 12.065 & $0.000^{*}$ \\
Fabrication & 0.114 & 4.321 & $0.000^{*}$ \\
Facilitating & 0.330 & 9.721 & $0.000^{*}$ \\
Plagiarism & 0.057 & 2.882 & $0.000^{*}$ \\
\hline Predictor: (constant), & MDP, & MDS, perceived \\
opportunity, collectivism, & organizational \\
religiosity, non-organizational & religiosity, \\
intrinsic religiosity. & & & \\
*) significant at 5\% & & &
\end{tabular}

Table 3

Regression Coefficient

\begin{tabular}{llllc}
\multicolumn{1}{c}{ Variable } & $\mathrm{DV}_{1}$ & \multicolumn{1}{c}{$\mathrm{DV}_{2}$} & $\mathrm{DV}_{3}$ & $\mathrm{DV}_{4}$ \\
\hline MDP & $0.313^{*}$ & 0.082 & $0.127^{*}$ & -0.015 \\
MDS & $0.318^{*}$ & $0.207^{*}$ & $0.457^{*}$ & $0.197^{*}$ \\
Perceived & $0.091^{*}$ & 0.000 & 0.032 & -0.010 \\
opportunity & & & & \\
Collectivism & $-0.071^{*}$ & -0.004 & 0.051 & 0.044 \\
Organizational & 0.065 & -0.023 & 0.045 & 0.000 \\
Non-organizat & -0.004 & $-0.165^{*}$ & -0.003 & -0.068 \\
ional & & & & \\
Intrinsic & -0.016 & 0.063 & 0.026 & -0.078 \\
\hline *) significant at 5\% & & & \\
$\mathrm{DV}_{1}=$ cheating & & & \\
$\mathrm{DV}_{2}=$ fabrication & & & \\
$\mathrm{DV}_{3}=$ facilitating academic dishonesty & \\
$\mathrm{DV}_{4}=$ plagiarism & & &
\end{tabular}

As presented in Table 3, not all of the dimensions were significant in predicting cheating, fabrication, facilitating, or plagiarism. Cheating was positively predicted by moral disengagement professor (MDP), moral disengagement student (MDS), and perceived opportunity, and negatively predicted by collectivism. That is, students with a high level of MDP, MDS, and the perceived opportunity were more likely to cheat. Students with low level of collectivism were also more likely to cheat. Fabrication was positively predicted by MDS and negatively predicted by non-organizational religiosity. Students with a high level of MDS or low level of non-organizational religiosity were more likely to do fabrication. Facilitating was positively predicted by MDP and MDS. Students with a high level of moral disengagement (MDP and MDS) were more likely to do facilitating. Plagiarism was positively predicted by MDS only. Higher level of MDS was associated with more likely to engage in plagiarism.

Table 4

Proportion of Variance

\begin{tabular}{|c|c|c|c|c|}
\hline Variable & $\mathrm{DV}_{1}$ & $\mathrm{DV}_{2}$ & $\mathrm{DV}_{3}$ & $\overline{\mathrm{DV}_{4}}$ \\
\hline MDP & $3.9 \%$ & $0.4 \%$ & $0.5 \%$ & $0 \%$ \\
\hline MDS & $34.9 \%$ & $8.7 \%$ & $31.8 \%$ & $4.2 \%$ \\
\hline $\begin{array}{l}\text { Perceived } \\
\text { opportunity }\end{array}$ & $0.7 \%$ & $0 \%$ & $0 \%$ & $0 \%$ \\
\hline Collectivism & $0.5 \%$ & $0.1 \%$ & $0.4 \%$ & $0.1 \%$ \\
\hline Organizational & $0.3 \%$ & $0.5 \%$ & $0.2 \%$ & $0.5 \%$ \\
\hline $\begin{array}{l}\text { Non-organizat } \\
\text { ional }\end{array}$ & $0 \%$ & $1.2 \%$ & $0 \%$ & $0.5 \%$ \\
\hline Intrinsic & $0 \%$ & $0.3 \%$ & $0.1 \%$ & $0.4 \%$ \\
\hline $\begin{array}{l}\mathrm{DV}_{1}=\text { cheating } \\
\mathrm{DV}_{2}=\text { fabricat } \\
\mathrm{DV}_{3}=\text { facilitat } \\
\mathrm{DV}_{4}=\text { plagiari }\end{array}$ & acau & sh & & \\
\hline
\end{tabular}


Table 4 illustrates the different proportions of variance in explaining academic dishonesty. It shows that the variance of academic dishonesty explained by MDS was higher than it is of other predictors.

\section{Discussion and Conclusion}

Discussion. As a result, all typologies of academic dishonesty were positively predicted by MDS. It is similar to Farnese's study which student that more consider academic dishonesty is "ok" for the student or everyone who do that were more likely to do academic dishonesty (Farnese et al., 2011). As for MDP only affected cheating and facilitating academic dishonesty. It means that students who tend to blame their teacher were more likely to engage in cheating or facilitating (Farnese et al., 2011). Similarly, students who see themselves as victims are also more likely to commit violating behavior. They also tend to do moral justification for the violation behavior it does, but deny it because of doing it not on humans, but on an object (Bandura et al., 1996). In this case is done on the exam or the execution of academic tasks. What is more, when an individual performs a behavior harming others for profit personal, or other person, the individual will eliminate or reduce consequences (Bandura et al., 1996).

Regarding to culture, collectivism variables has a negative and significant effect of cheating. One may argue that collectivism reduces the level of competition, and therefore would have a negative impact on cheating. But with the record that his group was the majority obeys the rules. It is as Singelis explains, et al. (1995) as that people with a collectivist culture place themselves as a part of the group. In achieving the goal, the individual prioritizes the group's goals (Singelis, Triandis, Bhawuk, \& Gelfand, 1995). The collectivism of the individual is characterized by good cooperation within the group, but will be a very different person outside the group as Triandis et al. (1988) has pointed out. It is contrary to Chapman and Lupton's study which student that self-oriented and did not care group goal, was more likely to do cheating (Chapman \& Lupton, 2004).

Cheating was also positively predicted by perceived opportunity. It was similar to Bolin's (2004) study, in which perceived opportunity both directly and indirectly predicted unethical behavior. The opportunity to cheat may lead to cheating behavior, especially if one had a favorable attitude toward cheating (Callanan, Rotenberry, Perri, \& Oehlers, 2010). Similarly, the study found that when faced with a dilemma, participants chose a more ethical solution when the opportunities for unethical conduct were low and the likelihood of getting caught was high, regardless of their ethical ideology. The result is also in line with DiBartolo and Walsh's (2010) study on corruption, which found that the extent and frequency of corrupt acts depended on the perceived opportunity to avoid detection of behavior and punishment.

Fabrication was also negatively predicted by non-organizational religiosity. It was similar to a study which reported that the more students engaged in religious activity and applying religious values, the less likely they engage in unethical behavior (Bloodgood, Turnley, \& Mudrack, 2007; Storch \& Storch, 2001). In this regard, therefore, religion may not only function as a guide of life in encouraging prosocial behavior but is also considered to deter oneself from engaging in deviant or problematic behavior (King \& Furrow, 2008).

The result of this study has some practical implications. First, this study found that academic dishonesty was largely associated with moral disengagement. That is, students would commit academic dishonesty if they did not feel guilty. Therefore, a system where students are accountable for their responsibility and assignment should be created and enforced. Second, collectivism also negatively predicted cheating. Therefore, individualist student was suggested to more socializing with their environment, so it also could be control of his behavior. Third, the perceived opportunity also affected cheating. Therefore, the policy on academic dishonesty should be made explicit and continuously socialized. Fourth, fabrication was also affected by non-organizational religiosity. Therefore, student can be encouraged to engage in religious activities and apply religious values.

This study also has many limitations. First, some the data were not normally distributed, so make sure when collected data. Second, the scale adaptation was very risky for social desirability and bias, especially culture bias. Therefore, equal the scale to your social demographic. Third, in this study has little in some variables, therefore try to use other variables beyond this study. 
Conclusion. In this study, the model was saturated. However, from four types of academic dishonesty, only two have a large of r-squared in this study, cheating and facilitating academic dishonesty. All of the dependent variables were predicted by MDS. While other the independent variables only predicted cheating (MDP, perceived opportunity, collectivism), fabrication (non-organizational religiosity), and facilitating academic dishonesty (MDP).

\section{References}

Aaron, U.B. (2004). Self-control, perceived opportunity, and attitudes as predictors of academic dishonesty. The Journal of Psychology; 138 (2) 101-114.

Bandura, Albert. (2002). Selective moral disengagement in the exercise of moral agency. Journal of Moral Education, 31 (2), 101-119.

Bloodgood, J.M., Turnley, W.H., \& Mudrack, P. (2007). The Influence of ethics instruction, religiosity, and intelligence on cheating behavior. Journal of Business Ethics.82. 557-571

Bolin, A. U. (2004). Self-control, perceived opportunity, and attitudes as predictors of academic dishonesty. The Journal of Psychology: Interdisciplinary and Applied, 138 (2), 101-114.

Brunnell, A.; Staats, S., Hupp, J \& Barden, J., (2010). Narcissistic student don't mind cheating their way to top. Journal of Personality and Individual Differences. 45 (2). 135-155.

Chapman, K. J., \& Lupton, R. A. (2004). Academic dishonesty in a global educational market: a comparison of Hong Kong and American university business students. International Journal of Educational Management, 18 (7), $425-435$.

Detert, J. R., Trevino, L. K., \& Sweitzer, V. L. (2008). Moral disengagement in ethical decision making: A study of antecedents and outcomes. Journal of Applied Psychology, 93 (2), 374-391.

Dewi, A. A. (2016). Pengaruh motivasi belajar dan orientasi religius terhadap tipe-tipe ketidakjujuran akademik pada mahasiswa. Jakarta: Fakultas Psikologi UIN Syarif Hidayatullah Jakarta.

Etter, S., Cramer, J.J., \& Finn, S. (2007). Origin of academic dishonesty: Ethical orientations and personality factors associated with attitudes about cheating with information technology. Journal of Research on Technology In Education, 39 (2), 133-155.

Farnese, M. L., Tramontano, C., Fida, R., \& Paciello, M. (2011). Cheating behavior in academic context: Does academic moral disengagement matter? Procedia Social and Behavioral Science, 29, 356-366.

Firdaus, W. M. (2017). Faktor-faktor yang memengaruhi perilaku ketidakjujuran akademik pada mahasiswa. Jakarta: Fakultas Psikologi UIN Syarif Hidayatullah Jakarta.

Fridayanti. (2015). Religiusitas, spiritualitas dalam kajian psikologi dan urgensi perumusan religiusitas islam. Psympathic, Jurnal Ilmiah Psikologi, 2 (2), 199-208.

Geddes, K.A. (2011). Academic dishonesty among gifted and high-achieving students. Spring 34 (2). 50-56.
George, Valerie. (2016). Academic integrity committee (AIC) summary report 2015-16. Florida: Academic Integrity Committee.

Giluk, T. L., \& Postlethwaite, B. E. (2015). Big five personality and academic dishonesty: A meta-analytic review. Personality and Individual Differences, 72, 59-67.

Harding, T. S., Carpenter, D. D., Finelli, C. J., \& Passow, H. J. (2004). Does academic dishonesty relate to unethical behavior in professional practice? An exploratory study. Science and Engineering Ethics, 10 (2), 1-14.

Hardy, S.A; Walker, L.J.; Rackham, D.D. \& Olsen, J.A.(2012). Religiosity and adolescent empathy and aggression: The mediating role of moral identity. Psychology of Religion and Spirituality. 4.(3). 237-248. DOI: $10.1037 / \mathrm{a} 0027566$.

Holdcroft, B. (2006). What is religiosity? Catholic Education: A Journal of Inquiry and Practice, 10 (1), 89-103.

Huelsman, M. A., Piroch, J., \& Wasieleski, D. (2006). Relation of religiosity with academic dishonesty in a sample of college students. Psychological Reports, 99 (3), 739-742.

Jones, D. L. (2011). Academic dishonesty: Are more students cheating? Business Communication Quarterly, 74 (2), 141-150.

Josephson Institute. (2012). 2012 report card on the ethics of American youth. Los Angeles: Josephson Institute of Ethics.

Jurdi, R., Hage, H. S., \& Chow, H. P. (2011). Academic dishonesty in the Canadian classroom: Behaviours of a sample of university students. Canadian Journal of Higher Education, 41 (3), 1-35.

Koenig, H., Parkerson Jr., G. R., \& Meador, K. G. (1997). Religion index for psychiatric research. The American Journal of Psychiatry, 154 (6), 885-886.

Ledesma, R. G. (2011). Academic dishonesty among undergraduate students in a Korean university. Research in World Economy, 2 (2), 25-35.

Little Circle Foundation. (2015). Data talk: Lebih dari 92\% dari mahasiswa Udayana pernah encounter. InCircle Journal Research \& Development. Diakses pada tanggal 29 Desember 2016 dari http://www.littlecirclefoundation.org

Martin, Daniel E. (2005). Plagiarism and technology: A tool for coping with plagiarism. Journal of Education for Business, 80 (3), 149-152.

Martin, Daniel E. (2011). Culture and unethical conduct: Understanding the impact of individualism and collectivism on actual plagiarism. Management Learning, $0(0), 1-13$

Mc. Donald, R., \& Carroll, J. (2006). Plagiarism-A complex issue requiring a holistic institutional approach. Assessment \& Evaluation in Higher Education, 31 (2), 233-245

Meng, C. L., Othman, J., D'Silva, J. L., \& Omar, Z. (2014). Influence of neutralization attitude in academic dishonesty among undergraduates. International Education Studies, 7 (6), 66-73.

Oyserman, Daphna. (1993). The lens of personhood: Viewing the self and others in a multicultural society. Journal of Personality and Social Psychology, 65 (5), 993-1009.

Paramitha, Winny N. (2016). Hubungan kontrol diri dengan kecurangan akademik pada mahasiswa fakultas teknologi informasi universitas kristen satya wacana (uksw). Salatiga: Fakultas Psikologi Universitas Kristen Satya Wacana.

Pavela, Gary. (1997). Applying the power of association on campus: A model code of academic integrity. Journal of College and University Law, 24 (1), 1-22. 
Purnamasari, D. (2013). Faktor-faktor yang mempengaruhi kecurangan akademik pada mahasiswa. Educational Psychology Journal, 2 (1), 13-21.

Randoplh-Seng, B., \& Nielsen, M. E. (2007). Honesty: One effect of primed religious representations. The International Journal For The Psychology of Religion, 17, 303-315.

Republik Indonesia. (2003). Undang-undang Republik Indonesia no. 20 tahun 2003 tentang sistem pendidikan nasional. Jakarta: Sekretariat Negara.

Reynolds, S.J., \& Ceranic, T. L. (2007). The effects of moral judgment and moral identity on moral behavior: An empirical examination of the moral individual. Journal of Applied Psychology. 92 (6), 1610-1624.

Sonnentag, T.L \& Mc. Daniels, B.L (2012). Doing the right thing in the face of social pressure: Moral rebel \& role models have heightened levels of moral trait integration. Self and Identity. DOI: 10.1080/15298868.2012.691639.

Stanescu, D. F. \& Iorga, E. M. (2013). Personality and academic dishonesty: Evidence from an exploratory pilot study. Revista Romana de Comunicare si Relatii Publice, 15 (1), 131-141.
Storch, E. A., \& Storch, J. B. (2001). Organizational, nonorganizational, and intrinsic religiosity and academic dishonesty. Psychological Reports, 88 (2), 548-552.

Syahrina, I. A., \& Andini, F. D. (2017). Self condfidence hubungannya dengan academic dishonesty pada mahasiswa fakultas ilmu komputer universitas $\mathrm{x}$. Psikovidya, 21 (1), 1-12.

Triandis, Harry C. (2001). Individualism-collectivism and personality. Journal of Personality, 69 (6), 907-924.

Triandis, H. C., Bontempo, R., Villareal, M. J., Asai, M., \& Lucca, N. (1988). Individualism and collectivism: Cross-cultural perspective on self-ingroup relationships. Jornal of Personality and Social Psychology, 54 (2), 323-338.

Underwood, J. \& Szabo, A. (2003). Academic offenses and e-learning: Individual propensities in cheating. British Journal of Educational Technology, 34(4), 467-477

Williams, K.M., Nathanson, C. \& Paulhu, D. L. (2010). Identifying and profiling scholastic cheaters: Their personality, cognitive ability, and motivation. Journal of Experimental Psychology: Applied. 16 (3), 293-307.

Wowra, S. A. (2007). Moral identities, social anxiety, and academic dishonesty among American college students. University of Phoenix. 